\title{
Introduction
}

\section{An Introduction to the Special Issue on Identity Politics}

\author{
Ashok Kumar \\ Birkbeck, University of London \\ a.kumar@bbk.ac.uk \\ Adam Elliott-Cooper \\ King's College London \\ adam.elliott-cooper@kcl.ac.uk \\ Shruti Iyer \\ Independent Researcher \\ shrutigiyer@gmail.com \\ Dalia Gebrial \\ London School of Economics \\ dgebrial@live.com
}

\begin{abstract}
This special issue responds to ongoing debates around what has been termed 'identity politics'. We aim to intervene in what are make-or-break questions for the Left today. Specifically, we wish to provoke further interrogative but comradely conversation that works towards breaking-down the wedge between vulgar economism and vulgar culturalism. Critically, we maintain that just as all identity categories are spatially and temporally contingent - socially constructed, yet naturalised - so too is this current bifurcation between 'class politics' and 'identity politics'. Ultimately, we
\end{abstract}


call for an intellectual and organisational embracing of the complexity of identity as it figures in contemporary conditions; being a core organising-principle of capitalism as it functions today, a paradigm that Leftist struggle can be organised through and around - and yet all with a recognition of the necessity of historicising, and ultimately abolishing, these categories along with capitalism itself.

\section{Keywords}

identity politics - economism - class - internationalism - culturalism - identitarian race - gender

2017 was, in many ways, the year debates around identity politics came to a head. No longer exclusively the stuff of intra-Leftist mudslinging, the contrived opposition between 'class politics' and 'identity politics' resurfaced in mainstream political and media parlance. After having spectacularly misjudged two of the West's most significant political shocks of the decade - Brexit and the election of Donald Trump - talking heads were quick to blame the rise of the far-Right on the crushing hegemony of 'political correctness'. This discursive framework purportedly side-lined the so-called 'white working class' in its desperate, emasculating attempts to appeal to women, people of colour and other marginalised communities.

Despite the categorically bourgeois interests behind the UK 'Leave' and 'Remain' campaigns, and the fact that, for example, lower-income Americans were less likely to vote for Trump than the upper classes, ${ }^{1}$ both moments were prematurely framed as cries of revenge from white, working-class men: a category defined by class as well as race, and yet dispossessed not by capitalism but by a multiracial metropolitan elite preoccupied with showing superficial tolerance towards minority identities. White nationalist and former Chief Strategist in Trump's White House, Steve Bannon, neatly summarised this framework - and its efficacy for his project of the so-called 'alt-right':

The Democrats - the longer they talk about identity politics, I got 'em.... I want them to talk about racism every day. If the left is focused on race and identity, and we go with economic nationalism, we can crush the Democrats. $^{2}$

1 Gould and Harrington 2016.

2 Steve Bannon, quoted in Egan 2017. 
Indeed, the set-up here becomes untenable for any serious, comprehensive Left project. The struggles of raced, gendered, sexual marginalities are situated in opposition to economic dispossession - which in turn, is experienced exclusively by white people, specifically white men, who curiously are not themselves implicated in a politics of identity-formation. In a further stretch of the imagination, the root of this economic dispossession is not located in the structural conditions of capital, but in the unjust squandering of resources on the less deserving - on migrants, people of colour and queer people. As such, resistance to this economic dispossession lies not in the dismantling of capitalism, but in the intensification of its racial and gendered violence: more incarceration, more detention and more jingoistic grandstanding. The implicit logic here is that the greater the dispossession of the racial and gendered Other, the higher the pile of scraps under the table of the capitalist class. Such a strategy effectively destroys all grounds for mass, anti-capitalist solidarity and resistance.

The original impetus for this Special Issue, which seeks to explicitly intervene in this contradictory discursive context, came in late 2015 - before the aforementioned political upheavals. It came in response to the Left's ongoing internalisation of these terms, and the cycle of self-defeat it was leading to. Indeed, just as all identity categories are spatially and temporally contingent socially constructed, yet naturalised - so too is this current bifurcation between 'class politics' and 'identity politics'. This opposition is itself a constructed, naturalised, and - crucially - effective innovation of the Right's many incarnations. It was clear to us that the Left's failure to articulate a compelling, rigorous history of identity-formation and, by extension, identity-oppression as rooted in capitalist dynamics left a dangerous explanatory vacuum. Furthermore, it created an organisational culture of individualised, positionality politics that precluded the possibility of broad-based co-operation - a necessity in the fight against capital in its contemporary form. If only the personal can be political, then solidarity ceases to be desirable - let alone achievable.

Tackling this mystification of the politics of identity-formation, the politics of capital and their mutual constitution, is an urgent site of intervention for Marxists today. As many of the contributions to this Special Issue show, there has been a fundamental ideological concession in the discourse regarding the role and nature of identity: of what we are talking about when we talk about identity. Chapters by Chi-Chi Shi and Annie Olaloku-Teriba in particular elegantly demonstrate how the Left has abrogated the notion of identity as being materially rooted, and contingent on historical and geographical context. In its place, we see the hegemonic acceptance of an inherently reactionary alternative: one which perceives race, gender and sexuality as dearly-held, 
self-fashioning and self-justifying essences. Such a concession has not only reinforced the class/identity binary, but led to a stifled political imagination in which identity-based politics can only be conceptualised within a liberalcapitalist logic. The acceptance and valorisation of one's identity as the both the start and end-point of politics leaves us with diversification within contemporary power structures as the only conceivable goal. Identity-based organising spaces have become an end in themselves, rather than being seen as part of the labour of building meaningful, constructive solidarity between oppressed groups. In turn, exploring one's personal identity is no longer the beginning of a deeper, theoretical exploration of oppression and resistance strategies, but the political project tout court.

A form of identity politics that has always strained resistance-movements one that conceals its roots in historical power-dynamics behind a fog of contradiction and homogenisation - has therefore emerged as dominant. This Special Issue aims to unpack this phenomenon, and begin to carve out alternative understandings of identity and its relationship to political economy. Specifically, the aim is to do this in a way that can effectively rise to the challenges of the contemporary world. It asks: how can we begin to understand identities such as race as not just - to extend Stuart Hall's formulation - a 'modality' in which class, and therefore capitalism, is 'lived', but also one through which its power is continually made and remade? Most importantly, how can we use such theoretical formulations as the guiding principle of our organisational strategies?

\section{Identity Politics and Neoliberalism}

Marxists have long made a case for the analytical connection between the rise of a particular kind of dematerialised identity-politics and neoliberal hegemony. It is within this academic trajectory that this intervention sits.

The story goes as such: in the West, the late 1960s and '7os saw the demise of a dominant form of capitalist production ('Fordism') - associated with high levels of employment, rising wages and increased welfare spending - all of which fed into a culture of mass consumption. The Fordist years are widely understood as a concordat between capital and labour, where the latter was allowed a minor share in the former's gains. Neoliberal measures championed by Reagan and Thatcher, however, brought this 'virtuous spiral' to an end, and a new kind of political organising grew. Surin identifies two popular positions concerning the rise of this new politics - one is that spreading prosperity under Fordism rendered a class-based politics less indispensable for working 
people, allowing new forms of collectivity to emerge (the civil-rights movement, and feminist, peace, ecology, and gay-liberation movements). ${ }^{3}$ The second prefers to see the growth of identity politics alongside neoliberalism as a quintessentially post-World War II American phenomenon, whereby a new multiculturalism emerged that was linked to the implementation of structural adjustment and Western-led humanitarian interventions. This operated as part of the US's need to assert itself within a context of newly-emerging independent states in Africa and Asia, along with the internationalisation of the world economy. ${ }^{4}$ In both interpretations, the identitarian conjuncture of the 1970 s is situated as distinct from any iteration that may have prefigured it; it is a historical break in which the predominant political articulations dethroned a more conventional idea of class-based politics. This reading sees identity politics as emerging from a historical moment that opposes the development of a mass anti-capitalist politics, and, being symptomatic of this failure, cannot possibly generate resistance to it.

Many of these assumptions are reflected in the debate between Axel Honneth and Nancy Fraser, where the two competing goods are those of 'recognition' and 'redistribution'. Recognition is the demand by oppressed groups that their distinctiveness be recognised, and the predominance of this vocabulary is occurring alongside the 'decline in claims for egalitarian redistribution' of material resources and goods. ${ }^{5}$ The demand for recognition is seen as the only viable demand that can be made, in a world where a credible 'feasible socialism' does not seem possible, and there remain doubts about the viability of the erstwhile Keynesian social-democratic order. ${ }^{6}$ Fraser identifies two problems with a politics of recognition - the first being that it displaces struggles for redistribution by remaining silent on economic inequality, and secondly that it reifies group identities in a manner that freezes them and offers no possibility of overcoming them. In this way, 'cultural proponents of identity politics simply reverse the claims of an earlier form of vulgar Marxist economism: they allow the politics of recognition to displace the politics of redistribution.' ${ }^{7}$ Fraser sees recognition as offering a valuable path for liberation, in that it can map-out a way to overcome the institutional misrecognition of oppressed groups (the status model), (i.e. racial profiling, homophobia, the stigma attached to single mothers, etc.) without valorising the specificity of

3 Surin 2009, p. 141.

4 Surin 2009, pp. 142-6.

5 Fraser 2000, p. 107.

6 Ibid.

7 Ibid. 
the group itself (the identity model). In confronting institutionalised discrimination, politics centred around recognition offer the possibility of seeing economic inequalities as barriers to full citizenship and participation in social life, tying the oppression of identity groups into questions around the distribution of and access to resources.

In this sense, identity politics is positioned in a variety of Marxist frameworks as ineffectual; as a politics founded on difference, it is inherently incapable of building the broad-based movement needed to destabilise capitalism. These arguments rely on seeing identity politics as not just historically linked to the neoliberal moment, but a manifestation of a neoliberal logic itself. Under the thesis that neoliberalism is not simply an economic moment, or set of economic policies, but a logic unto itself - turning 'all conduct into economic conduct' - identity politics has been understood as a configuration of this neoliberal rationality. Where neoliberalism economises previously noneconomic spheres and practices, the human being now becomes human capital, and 'is both a member of a firm, and itself a firm. ${ }^{9}$ Indeed, according to Feher, the primary distinction between the neoliberal subject and the subjects that preceded her is that homo economicus is now concerned with enhancing its portfolio value in all domains of life.

So how might identity politics figure into this idea of neoliberal rationality? For one, as the Foucauldian narrative goes, the hallmark of neoliberal reason is competition, the market's root principle. Political collectivities formed around insular, demarcated (albeit frequently-changing) identities might therefore be conceived as groups competing for representative primacy and limited resources. As Adolph Reed ${ }^{10}$ and Walter Benn Michaels ${ }^{11}$ put it, on this model of identitarian liberation, capitalist society is faultless for as long as, within the $1 \%$ that controls $90 \%$ of all resources, there is a proportional representation of women, racial minorities, and LG в identifies discourses which lead to groups like Black Lives Matter presenting racism in policing and prisons as somehow separate from capitalism. ${ }^{12}$ While he chooses a media interview from a BLM activist, rather than the material the movement itself produces (which is quite explicit about the links between capitalism and prisons), his critique speaks to a wider trend in categorising prisons as a 'race' problem, and universal healthcare and free education as

\footnotetext{
8 Brown 2015, p. 10.

$9 \quad$ Brown 2015, p. 34 .

10 Reed 2016.

11 Benn Michaels 2008, pp. 34ff.

12 Reed 2015.
} 
offering a class-reductionist approach to social injustice. Much of this critique, articulated by both Adolph Reed and Touré Reed, is linked to their frustration with anti-racism overlooking the ways in which the Bernie Sanders campaign disrupts neoliberal hegemony. While groups like BLM are dissatisfied with Sanders's position on policing and prisons, their aforementioned critics consider the commitments to healthcare, education and other socialdemocratic policies as a fundamentally positive contribution to struggles for social, economic and racial justice. This conception of identity politics also opens it up to critique on the lines of strategy - whereby collectives organised around the principle of difference will be reduced to trying to win concessions under capitalism for the groups that they represent. Therefore, since political affiliations organised around differential identity brackets cannot confront capital or class, it ought to be dispensed with.

Brown identifies this sort of despair as part of a neoliberal logic, that market institutions are unassailable and that there is no prospect of change. ${ }^{13}$ Rather, these critics see identity politics as itself a manifestation of class politics: the class politics of a 'professional-managerial class' which does not seek to dismantle class structures - considering this either impossible, or perhaps even undesirable - but seeks instead to ensure the representation of minorities among the capitalist class. Replacing an analysis that situates capitalism at its heart, the root of systemic injustice in popular discourse is then increasingly relegated to the ahistorical and individualising domain of 'intolerance' and 'prejudice'. It is then no surprise that the rise of this mode of political organisation and, most crucially, political imagination, happens through and alongside the dismantling of unions and of the possibility of envisioning an alternative to a world thoroughly marketised.

This is not to reject all forms of identity-based movements as unfortunate mistakes - or worse, 'false consciousness'. Indeed, even these critics admit to there being a utility to identity politics when leveraged against the state for legal remedies - but the contestation is that this strategic, or operational, essentialism must be only that - it cannot contribute to a political vision of liberation, or even one that sees anti-racism and women's liberation as part of a programme for social justice. In part the claim is that ascriptive identities (like race, gender, or sexual orientation) shift from being understood as, to extend Stuart Hall's formulation, modalities through which class is 'lived' and experienced, ${ }^{14}$ to attributes of individuals that attach to them. It becomes part of their 'portfolio', categorising individuals on the basis of what they are rather

\footnotetext{
13 Brown 2015.

14 Hall and du Gay (eds.) 1996, p. 51.
} 
than what they do. In this sense, identity operates as a commodity, whereby the historical specificity of racism and sexism's emergence through and alongside a capitalist mode of production is mystified.

The emergence of identity politics is therefore also embedded in the liberaldemocratic state, and the ability to mobilise around gaining concessions or formal rights from it. These are, in the liberal-democratic framework, intended to translate into material and symbolic equality. The precondition for this collectivisation, however, is the claim that the collective group is oppressed and has been injured in some way. Brown cautions that this approach politicises identity by re-entrenching its own pain, and its continued success is contingent on not overcoming this pain; in other words, the collective identification is premised on a past exclusion rather than the capacity to imagine future liberation..$^{15}$ Nair goes further, saying that the ideal subject of neoliberalism is a subject of trauma, and that the corollary, in movements, is a culture of confessing one's individual trauma, necessitating a certain personal experience and fulfilling a demand for authenticity that is seen to stifle organising rather than creating the conditions for solidarity and effective resistance. ${ }^{16}$

The question remains, however: given their predominance in the contemporary moment, can identitarian movements be a viable part of anti-capitalist political formations? What character would they take, if so? Can identity collectives be predicated on their own eventual destruction, or do they necessarily solidify the formations they seek redress for? It remains unclear whether they offer no meaningful interim reparation, or that the moment of their emergence necessarily precludes these movements from taking on an anti-capitalist character. Of course, a politics of identity that is simply an extension of liberal democracy, and only conceives of itself in those terms, ought to be dismissed outright as having any revolutionary prospect (and, it must be added, they have no pretensions of having any). And as Surin points out, there have been a number of historical struggles that confronted economic dispossession in a way that has centred gender- and race-analysis as core modes through which such dispossession has been made possible (such as the Zapatista movement in the Chiapas, or the Wages for Housework movement). Perhaps it remains most useful not to see identity movements as having supplanted class-based organising, but as a development that is itself structured by a continuing class conflict, regenerated by the financial crisis of 2008 and continued through the political crises of 2016. But if identity movements are to have anti-capitalist

\footnotetext{
15 Brown 2015.

16 Kinnucan 2014.
} 
energy, the abolition of class and identity distinctions will have to be part of their vision for the future, the society that they struggle for.

The critique of identity politics in recent years has been shouted loudest by the Right. Reducing a range of struggles which decentre the West, or overtly problematise whiteness, to matters of 'identity' is used to dismiss critiques of European imperialism and its legacies. Yet, it is the identity politics mobilised by the Right which has seen Empire recaptured in the minds of Europe's citizens most effectively. Take the UK referendum to remain or leave the European Union, as a case-in-point: we witnessed the evocation of Britishness, and by extension whiteness, as an identity, mobilised through a range of signifiers and symbols.

While Britain's political establishment was somewhat divided on the issue, those in the Leave camp seized the moment, in an unmasking of their tacit racism which was shocking to some. When Barack Obama made a presidential visit to Britain, urging it to remain in the European Union, Boris Johnson, future Secretary of State for Foreign Affairs, remarked that Obama holds Britain in contempt due to his Kenyan roots. Combining an acknowledgement of imperial crimes with the ongoing nostalgia for Empire itself was perhaps only shocking as far as it was directed at the head of the old Empire's most successful legacy. Yet it is Brexit which provided the antidote to both Britain's postimperial melancholia and the political correctness (now apparently thrusted upon Britain from a European, rather than a darker outsider) which dampens its proud legacies. The popularity of this white identitarianism was not missed by the press, hoisting the far-right politician Nigel Farage to public stardom. Even the often-liberal Channel 4 News invited Farage into the studio to discuss Empire, as the living survivors of Britain's gulags in 1950s Kenya forced their old colonial masters to publicly acknowledge their crimes. Neither lawyer nor historian, Nigel Farage's sole purpose was to posit an identitarian position, reassuring viewers that 'white British' was an identity of which to be proud, and importantly, an identity under attack. Flip-flopping between post-colonial immigration threats and those from Continental Europe was, and remains, a seamless transition. Farage's UKIP demonstrated this with their flagship advertising campaign, which identified the apparent failings of EU migration policy with an image of darker-skinned migrants who have come from beyond Europe's borders, falsely implying that it is EU membership which leads to migrants from beyond Europe entering the UK. 
But, of course, herein lies the power of identity politics - even the most basic level of consistency can be explained away, with Leave voters citing a range of xeno-racist explanations from their position. From the threat of 'radical Islam' or the job-seeking Europeans, to the ominous slogan 'Take Back Control', with clear echoes to the equally nostalgic 'Make America Great Again' being sung across the Atlantic. Interestingly, both Brexit and Trump were interpreted by many on the liberal-Left as being part of a working-class (read: white working-class) revolt. The conceit that the xeno-racist bigotry of Brexit/Trump is the preserve of the (white) working class is not particularly new to the common sense of the liberal establishment. But the platforms afforded to the extreme-Right by the liberal press, as citizens in both the US and Europe went to the ballot box, points towards an encouragement of such a (white) uprising (in times of working-class dissent, the liberal media affirmed a dangerous historical precedent that it is the Right which has the knowledge and the answers). While the complementary relationship between liberalism and white racism has long been documented, ${ }^{17}$ it is within this political moment that far-right and fascist forces, emerging from Europe and North America's capitalist class, were presented as something quite different. Studies following the election of Trump and the British referendum on Europe clearly indicate that working-class people, racialised as white, were not the primary demographic driving these reactionary electoral outcomes. ${ }^{18} \mathrm{~A}$ complex mesh of educational attainment, property-ownership, public/private-sector work, age and, of course, race, appear to be stronger determinants as to the position taken in these battles over identity.

Further-cementing of the white politics of identity became apparent with Prime Minister Theresa May's post-Brexit international tour. Visiting Australia, New Zealand, Canada and the United States, the Conservative government enthusiastically championed more migration between these historically aligned white-settler colonies. No longer a colonial favourite, South Africa was left off the list of former colonies with which Britain wished to maintain such close ties. And while Modi's India has been widely praised by Britain's political class, his proposal for skilled migrants to be afforded more-open access to a post-Brexit Britain was swiftly rejected. Consistent with the rhetoric around international migration, the greatest indicator of how the identity politics of whiteness remains wrapped up in establishment politics is perhaps its foreign policy. While some commentators speculated that Trump's election could lead to isolationism on the part of America, US aggression in Syria and towards

17 Césaire 2000.

18 Bhambra 2018. 
North Korea suggests otherwise. As Sai Englert points out in his analysis of identification with Israel and the Trump campaign in this special feature, even the rampant antisemitism of these white nationalisms has done little to deter white identities globally, which continue to mark the international fault-lines which facilitate the settler-colonial project taking place in what was formerly Palestine. Indeed, the violence of white nationalisms which have emerged across Anglo-America since the Trump-Brexit alliance began to take hold may well be reproduced on the international scale. This should perhaps come as little surprise, for a movement which relies so heavily on a whitened version of an imperial past.

\section{Identity Politics and the International}

Beyond the Anglo-American context within which the editors of this special feature are situated, identity politics has also been mobilised across the postcolonial world. Two key examples are the principal regional powers in Southern Africa and South Asia: South Africa and India. In India, the identity politics of Hindu nationalism has gone further in strengthening neo-colonial capitalism and repressing the darker masses. While the BJP espouses a nationalism that, it often argues, is anti-colonial, in its harking-back to a pre-colonial Hindu culture it has in fact re-entrenched neoliberalism. Constructing an identity politics, it has imposed a school curriculum promoting Sanskrit, but also the literature of the Hindu-nationalist Rashtriya Swayamsevak Sangh organisation and a patriotic 'Defence Studies' used to legitimise BJP reforms. Like the farRight in Europe and North America, the BJP has blamed the inequalities of neoliberal capitalism on liberal elites which favour national minorities, such as Muslims. ${ }^{19}$ Thus, neoliberalism continues to shape the political economy of the subcontinent, with its reproduction cemented, and resistance to it repressed, through a populist party defined by identity.

In South Africa, on which Richard Pithouse writes, identity politics is continually mobilised to promote a black capitalism which has left the vast majority of black South Africans as impoverished as they were during apartheid. The ANC's shift towards a neo-colonial capitalism has been masked with a rhetoric championing a black capitalism. The rhetoric of the latter is demonstrated through BEE, the Broad-Based Black Economic Empowerment Act of 2003, the promotion of economic transformation to 'enable meaningful participation of black people in the economy' (Section 2(a)). It has, however, only reached a 
thin layer of South Africa's black population, ${ }^{20}$ particularly those with close links to the ANC government. ${ }^{21}$ For example, the ANC-aligned owners of the wine industry have used BEE to avoid land redistribution and improvements in worker conditions. ${ }^{22}$ Moreover, a BEE deal involving state forests in Komatiland had to be cancelled after the recipient, Mcebisi Mlonzi, was accused of paying R55,000 to Andile Nkuhlu, chief-director of the Department of Public Enterprises, before the deal was sealed. ${ }^{23}$

Frantz Fanon grappled with the pitfalls of the post-colonial state, as the black bourgeoisie serviced the former colonial masters, manifested in the enduring presence of white monopoly-capital in South Africa. As Paul Gilroy puts it, anti-racism prescribes us

the pious ritual in which we always agree that 'race' is invented but are then required to defer to its embeddedness in the world and to accept that the demand for justice nevertheless requires us to enter the political arenas that it helps to mark out. ${ }^{24}$

Yet, in attempting to overcome such a contradiction, he affirms that identity should be the basis for our politics, not our politics in-itself. Thus, it is being racialised as black, and all that it brings, that provides the basis for the radical anti-racist, anti-capitalist and anti-imperialist politics of social movements in South Africa, and many other post-colonial contexts. Navigating this strategic deployment of identity is urgent in both the under and over-developed worlds. But rather than making clear divisions between them, this Special Issue instead focuses on the genealogies of identities, their relationship with the state and the extent to which they can help or hinder solidarities.

This Special Issue is organised into three sections: genealogies, the state, and solidarity.

\footnotetext{
$20 \quad$ Nattras and Seekings 2001, p. 66.

21 Bond 2004.

22 See Du Toit, Kruger and Ponte 2008.

23 Gumede 2005, p. 296.

24 Gilroy 1998, p. 842.
} 


\subsection{Genealogies}

We begin with Marie Moran's 'Identity and Identity Politics: A CulturalMaterialist History'. Moran analyses the relationship between economic transformation and political struggle by following the changing meaning and application of the word 'identity' throughout the twentieth century. Moran argues that the emergence of the central role of identity in social and political practice is an outgrowth of particular social forces and pressures. In this context, prior to the 1950 s identity was discussed only by a small group of philosophers and in a fundamentally different way to how it has emerged in popular culture since the 1950s. Identity politics in its more contemporary form arose in the second half of the twentieth century as a direct response to the inequalities of the postwar consumer boom. In short, through the changing articulation of 'identity' and its move, over time, from the political periphery to its core, 'identity' in its current expression is both specific to advanced capitalism and a historical novelty.

In March 2016, at the height of her campaign for the White House, Hillary Clinton effusively tweeted about the 'complex, intersectional set of challenges' faced by the United States. Whether it was Clinton herself or a high-priced social media strategist behind the tweet is neither here nor there; what is clear is that intersectionality is now part of popular parlance and hegemonic discourse. In 'Intersectionality and Marxism: A Critical Historiography', Ashley Bohrer situates the emergence and proliferation of intersectionality against and within a Marxist-Feminist framework. These debates have rested on the antagonism between Marxism, which tends to cast gender and race as secondary or epiphenomenal to class, and intersectionality, in which class remains underdeveloped or absent altogether. Ultimately, Bohrer locates capitalism as the source of modern class, gender, sexuality, and race-based systems of oppression but does not position class as the primary or privileged axis of oppression. As such, an intersectional Marxism is necessary to both understand capitalist exploitation and oppression and mobilise to overthrow it.

Hannah Proctor's 'History from Within: Identity and Interiority' is best read as a critique of the critiques of identity politics. It aims to break with some of the conditional reflexes in debates over identity politics, in particular the assumption that considerations of subjective experience somehow invariably reify liberal individualism. In this kaleidoscopic approach, Proctor delves into twentieth-century psychological texts that preceded the 'age of identity politics', drawing on seemingly disparate experiences to draw out the distinction between identification, recognition, integration and subjectivity. Proctor argues against Fraser and others that individual psychology is indeed interwoven with identity - and thus social relations - suggesting that cognitive 
capacities correspond to externally-manifest social attributes and material conditions. Finally, Proctor critiques a normative impulse in Fanon via Moten, explaining this latter's politics of non-identity, non-recognition and non'framing' (as against identity politics through a demand for recognition). Ultimately, Proctor helps complicate the contemporary formations of identity by exploring the political importance of interiority. In doing so she breaks with the linear understanding of the relationship between the social and the psychological - asking how the social informs the psychic and how the psychic informs the social.

In 'Afro-pessimism and the (Un)Logic of Anti-Blackness' Annie OlalokuTeriba examines the formation and limitations of 'anti-Blackness' as a theory and a practice. Olaloku-Teriba understands 'Anti-Blackness' in its Afropessimistic formulation. In this dominant variant, the basis for 'anti-blackness' is a uniform, transhistorical and universal racial hierarchy, and static categories with white people at the top and black people at the bottom. In this social order, proximity to whiteness determines one's place on the ladder. Consequently, the charge of 'anti-blackness' is mobilised against non-black people of colour. The theory and its practice, Olaloku-Teriba argues, emerged due to number of factors including the collapse of diverse political traditions represented in the black-liberation struggles of the 1960s and the separation between domestic (anti-racist) and international (anti-imperialist) resistance. Through historical analysis, Olaloku-Teriba wrenches back the Black Panther Party and Frantz Fanon from the pessimists, reclaiming them for revolutionaries. She uses Huey P. Newton's concept of intercommunalism, with its conception of race as historically contingent and its aim to abolish race altogether, as a rejoinder to theories of Afro-pessimism. Ultimately, Olaloku-Teriba intervenes in contemporary debates through a critique of the growing Afro-pessimism literature, in an attempt to revive the idea of racial solidarity and the possibility of revolutionary politics.

\subsection{The State}

In 'Feminism Against Crime Control' Koshka Duff addresses the tension between the struggle against sexual violence and seeking justice through the criminalising state. How can the power of the state - perhaps the biggest single perpetrator of sexual violence - be wielded against perpetrators of sexual violence? Are we condemned to be either rape apologists or state apologists? To answer this, Duff disrupts these entrenched battle-lines by exploring the work of Catharine MacKinnon - known as the most important theorist and advocate of 'Governance Feminism'. Duff, in a similar vein to Chi-Chi Shi's paper, situates these debates within the current of 'identity thinking', whereby a critique 
of the carceral state can reproduce its logic - which relies on a clear victim/ perpetrator binary - outside the state, leading Duff to highlight the need for a more complicated engagement with a multifaceted and contradictory state.

In 'The State, Zionism and the Nazi Genocide', Sai Englert interrogates the relationship between Jewish identity, Zionism and official Holocaust memory, as shaped by contemporary identity-politics discourse. Englert describes two distinct but overlapping formations of Jewish identity, one shaped by and for the needs of the settler-colonial state and another constructed through political contestation. Englert argues that despite the rationale of preventing antisemitism, state-led antisemitism has resulted in the Jewish community's identification with Israel and Zionism and a whitewashed reading of the Nazi genocide that obscures the role of Western states and capital.

Richard Pithouse's 'Forging New Political Identities in the Shanty Towns of Durban, South Africa' sets up two conflicting paths to political power in South Africa - accumulation via the state (authoritarian nationalism organised around forms of clientelism) and accumulation via the market (racial capitalism). However, notwithstanding this conflict between elites, the mandarins of the state and the proprietors of capital found common ground against popular movements. To support this claim, Pithouse takes us through a political history of post-apartheid South Africa and the discursive disjuncture between the articulation of 'identity politics' by political elites and the exercise of popular politics by counter-elites or 'ordinary citizens'. The result has been a deepening fissure between party politics and popular politics, and between established trade-unions and social movements.

\subsection{Solidarity}

Peter Hudis's 'Racism and the Logic of Capital' speaks to Fanon's understanding of the production of race-class, and race taking on a life of its own. Rather than abandoning class analysis, Fanon expands it into a more relational understanding of society and change. The thesis that racism is 'at the inner core of the dialectic of capital accumulation' rests on two lines of argument: that capitalism emerged on the basis of the Atlantic slave-trade, and that the ensuing racism has had a unique impact on its victims by reaching down into a psychic level deeper than anything found in the relation between capital and labour. If the slave-trade is proof that racism is at the inner-core of capital, then the key question remains: can there be capitalism without racism, or was racism built into modern capitalism through certain historical events? Is racism truly essential to the operations of capital (on a par with the extraction of surplusvalue), or rather is it a matter of contingent history? Alongside interrogating Fanon's understanding of these questions, Hudis delves into Fanon's critiques 
of the fixed and essentialising tendency of Negritude. Critically, Hudis's article is an implicit argument against Afro-pessimist misreadings of Fanon and its relation to Marxism, and should be read as a companion to Annie OlalokuTeriba's paper.

Lucy Freedman's 'A "Beautiful half hour of being a mere woman": The Feminist Subject and Temporary Solidarity' observes the role of gender identity in addressing the contentious and seemingly-intractable debate over womanhood. Drawing on the poetry of Loy and experiences of gender-based activist groups, Freedman describes a world in which solidarity and identity have become antagonistic. Borrowing the concept of 'soft abolitionism', Freedman argues for a deeper analysis of temporality to find an alternative to the binarity of identity and identity-abolition. Freedman explores the relationship between class formation and gender-oppressed people, asking: when do women and others oppressed by gender move from being a mere collection of individuals sharing a common experience, toward a collective acting with shared interests to challenge and even abolish these categories? Freedman argues that a more malleable and temporary gender-identification could enable solidarity among women and gender-queer people. To Freedman, temporary gender-identification provides an answer to an impasse arising from long-standing contradictions in feminist politics - the tension involved in a choice between reifying gender or an undermining of its own basis for connecting subjects.

In recent years, debates over the political relevance of cultural appropriation have often served as a heated dividing-line between radicals and radicalliberals. In 'Cultural Formation and Appropriation in the Era of Merchant Capitalism, William Crane situates this question within the transition-tocapitalism literature to identify a place and time when the discourse of cultural appropriation went wrong. Crane historicises the emergence of cultural signifiers, taking the spice and textile trade of the Dutch United East India Company (Voc) and the slaves and sailors recruited by the voc as early examples of cultural formation as a process of the appropriation of human labour. In this context, Crane argues, cultural appropriation is more appropriately understood as the cosmopolitanism of capital and labour.

Chi-Chi Shi's paper, 'Defining My Own Oppression: Neoliberalism and the Demands of Victimhood', addresses a central paradox of the form of identity politics that has grown out of neoliberalism, positing the question: 'why do we look for recognition from the very institutions we reject as oppressive?' To Shi, contemporary activist-circles maintain a contradictory position in their praxis. While 'identity politics' itself is derided, in practice identity, with its emphasis on experiential accounts of oppression, has become a barometer of legitimacy. 
'The collective' conceived through intentional construction, as a product of agency and with a final aim towards dismantling the oppressions themselves, is now congealed through experiences of trauma produced by the structures of domination. From this, Shi unpacks how frameworks of 'intersectionality' once introduced as a rejoinder to identity politics - have come to function as its new iteration. Here, differential identities are continually multiplied, flattened-out and naturalised in the name of representation and recognition a process that sacrifices analytical depth for an unavailing form of breadth. The result of this political culture, organised ostensibly in opposition to these systems of oppression, is to make these social relations more durable.

At its core, the aim of this Special Issue is to intervene in what are makeor-break questions for the Left today. Specifically, we hope to provoke further interrogative but comradely conversation that works towards breaking down the wedge between vulgar economism and vulgar culturalism. We call for an intellectual and organisational embracing of the complexity of identity as it figures in contemporary conditions; being a core organising-principle of capitalism as it functions today, a paradigm that Leftist struggle can be organised through and around - and yet all with a recognition of the necessity of historicising, and ultimately abolishing, these categories along with capitalism itself.

Critically, this work is not new. Looking back at the legacies of our strongest points in history - from the Black Panthers, to Fanon, to radical queer interrogations of gender - we stand in a long tradition of reconciling the material and the symbolic as inextricable components of oppression today. We invite scholars and activists to review this history, and re-orient its questions to the present day. In particular, we invite people to engage with areas that we did not cover - particularly around the pressing issues of Islamophobia, sexuality and debates around digital technology and subjectivity.

Finally, this volume would not have been possible without the (often thankless) labour of dozens of scholars who served as blind peer-reviewers - we extend gratitude for their work.

\section{References}

Benn Michaels, Walter 2008, 'Against Diversity', New Left Review, II, 52: 33-6, available at: <https://newleftreview.org/II/52/walter-benn-michaels-against-diversity $>$.

Bhambra, Gurminder K. 2017, 'Brexit, Trump, and "Methodological Whiteness": On the Misrecognition of Race and Class', The British Journal of Sociology, 68, S1: 214-32.

Bond, Patrick 2004, 'The ANC's "Left Turn” \& South African Sub-imperialism', Review of African Political Economy, 31, 102: 599-616. 
Brown, Wendy 2015, Undoing the Demos: Neoliberalism's Stealth Revolution, New York: Zone Books.

Césaire, Aimé 2000, Discourse on Colonialism, translated by Joan Pinkham, New York: Monthly Review Press.

Du Toit, Andries, Sandra Kruger and Stefano Ponte 2008, 'Deracializing Exploitation? "Black Economic Empowerment" in the South African Wine Industry', Journal of Agrarian Change, 8, 1: 6-32.

Egan, Timothy 2017, 'What if Steve Bannon Is Right?', New York Times, 25 August, available at: <https:/www.nytimes.com/2017/08/25/opinion/bannon-trump-polls -republican.html>.

Fraser, Nancy 2000, 'Rethinking Recognition', New Left Review, II, 3:107-18, available at: $<$ https://newleftreview.org/II/3/nancy-fraser-rethinking-recognition>.

Gilroy, Paul 1998, 'Race Ends Here', Ethnic and Racial Studies, 21, 5: 838-47.

Gould, Sky and Rebecca Harrington 2016, '7 Charts Show Who Propelled Trump to Victory', Business Insider, 11 November, available at: < http://uk.businessinsider.com/ exit-polls-who-voted-for-trump-clinton-2016-11>.

Gumede, William Mervin 2005, Thabo Mbeki and the Battle for the Soul of the ANC, Cape Town: Zebra Books.

Hall, Stuart and Paul du Gay (eds.) 1996, Questions of Cultural Identity, London: SAGE Publications.

Kinnucan, Michael 2014, 'An Interview with Yasmin Nair, Part Two: The Ideal Neoliberal Subject Is the Subject of Trauma', Hypocrite Reader, August, available at: <http:// hypocritereader.com/43/yasmin-nair-two $>$.

Nattrass, Nicoli and Jeremy Seekings 2001, “"Two Nations?” Race and Economic Inequality in South Africa Today', Daedalus, 130, 1: 45-70.

Reed Jr., Adolph 2016, 'How Racial Disparity Does Not Help Make Sense of Patterns of Police Violence', nonsite.org, 16 September, available at: <http://nonsite.org/ editorial/how-racial-disparity-does-not-help-make-sense-of-patterns-of-police -violence $>$.

Reed, Touré F. 2015, 'Why Liberals Separate Race from Class', Jacobin, 22 August, available at: <https://www.jacobinmag.com/2015/o8/bernie-sanders-black-lives-matter -civil-rights-movement>.

Surin, Kenneth 2009, Freedom Not Yet: Liberation and the Next World Order, Durham, NC: Duke University Press.

Vanaik, Achin 2001, 'The New Indian Right', New Left Review, II, 9: 43-67, available at: $<$ https://newleftreview.org/II/9/achin-vanaik-the-new-indian-right>. 